CIRJE-F-819

\title{
Stock Price Targeting and Fiscal Deficit in Japan: Why Did the Fiscal Deficit Increase during Japan's Lost Decades?'
}

\author{
Shin-ichi Fukuda \\ University of Tokyo \\ Junji Yamada \\ Graduate School of Economics, University of Tokyo
}

October 2011

CIRJE Discussion Papers can be downloaded without charge from:

http://www.cirje.e.u-tokyo.ac.jp/research/03research02dp.html

Discussion Papers are a series of manuscripts in their draft form. They are not intended for circulation or distribution except as indicated by the author. For that reason Discussion Papers may not be reproduced or distributed without the written consent of the author. 


\title{
Stock Price Targeting and Fiscal Deficit in Japan: Why Did the Fiscal Deficit Increase during Japan’s Lost Decades?*
}

\author{
Shin-ichi Fukuda (University of Tokyo) \\ Junji Yamada (University of Tokyo)
}

\begin{abstract}
The purpose of this paper is to explain why Japan's fiscal deficit increased so dramatically in the 1990s and the 2000s. We focus on the role of "stock price targeting” to explain why the fiscal expenditure increased so much. After presenting a simple model to describe government behavior with an optimistic view about stock price and output growth, the paper tests whether the model can explain Japan’s fiscal expenditure. The empirical results, using biannual and highfrequency data of the 1990s and the 2000s, show that the stock price targeting can track Japan's fiscal expenditure reasonably well, especially in the 1990s. They imply that without the stock price targeting, the total amount of biannual fiscal stimulus from 1992 to 2000 would have been lower by 2.5 trillion yen on average.
\end{abstract}

Key Words: fiscal deficit, government spending, stock price

JEL \#: H62, H50, H30, H12.

\footnotetext{
* An earlier version of this paper was presented at the TRIO conference held at University of Tokyo on December 16-17, 2010, and at the 2011 APEA conference held at Pusan National University on June 2425, 2011. We would like to thank Yosuke Takeda, Takeo Hoshi, Takatoshi Ito, and other participants for their helpful comments. Fukuda's research was partially supported by the Ministry of Education, Science, Sports and Culture, Grant-in-Aid for Scientific Research (B).
} 


\section{Introduction}

After the global financial crisis, accumulated fiscal deficits became one of the most urgent issues to be addressed in most OECD countries. According to the OECD Economic Outlook 89, the OECD average ratio of general government gross financial liabilities to nominal GDP, which was $73 \%$ in 2007 , is projected to increase to $105.4 \%$ in 2012 , the highest in the past half century. However, comparing fiscal deficits across countries, one finds Japan has accumulated a much higher deficit than any other OECD country. Measured by general government gross financial liabilities, Japan’s fiscal liabilities were twice as much as the nominal GDP in 2010. This ratio suggests that Japan's fiscal deficit is much more serious than that of any of the PIGS countries (Portugal, Ireland, Greece, and Spain) that faced fiscal problems after the global financial crisis. The general government financial liabilities, even after government assets are subtracted from them, are estimated to exceed nominal GDP after 2009. In terms of GDP, Japan’s liabilities were the highest among the OECD countries after 2008.

Until the mid-1970s, Japan had been an exceptional country, with little fiscal imbalance. The ratio of government bonds outstanding to GDP was 3.7\% in 1970 and $9.9 \%$ in 1975 . Even in the early 1990s, gross government liabilities were close to the OECD average and net liabilities were far below the average. However, from 1992 to 2000, gross liabilities doubled and net liabilities quadrupled (see Figure 1). This upward trend was further accelerated after the global financial crisis. Japan’s fiscal deficit became exceptionally high in the 1990s and the late 2000s.

The purpose of this paper is to explain why Japan's fiscal deficit increased so dramatically in the 1990s and the 2000s. One of the straightforward reasons for this is that Japan had a prolonged stagnation during this period. However, although this period is sometimes called the “lost two decades," average growth rates in Japan at the time were not exceptionally low compared to other OECD countries. Table 1 summarizes the average annual growth rates of selected OECD countries in the 1990s and the 2000s. Japan's growth rates were lower than the OECD average. They were also slightly lower than that of France, almost equal to that of 
Switzerland, and slightly higher than that of Italy. Given the fact that these countries' fiscal expansion was much less dramatic than that of Japan, Japan's slow economic growth is not enough to explain the exceptional increases in its fiscal deficit in the 1990s and the 2000s.

In contrast, comparing the stock price indexes of major OECD countries, we see a unique feature in Japan from the late 1980s through the 2000s. The Japanese stock market experienced a “speculative bubble” in the late 1980s: The Nikkei 225 Average Index, which was less than 10,000 yen in December 1984, rose to 30,000 yen in December 1988 and to almost 40,000 yen in December 1989. The overvalued stock prices, however, did not persist. After the burst of the speculative bubble in January 1990, the Nikkei Average Index fell below 20,000 yen in early 1992 and experienced further declines from 1998 to 2003 during the banking crisis. Such dramatic declines in stock price had never been observed in other developed countries in the 1990s and the 2000s before the global financial crisis.

When the stock price is substantially overvalued, its dramatic decline is inevitable. No government policy can stop the decline until the price is adjusted to its fundamental value. This dramatic price decline, however, causes a serious problem from a political point of view. Ordinary people do not have enough knowledge about what is the fundamental value of the stock price or what is the definition of a speculative bubble. The politicians then face pressure from the public to implement expansionary policies to stop the continual asset price decline. In the 1990s, such a situation existed in Japan. ${ }^{1}$ This called for excessive expansion of fiscal expenditure despite declining tax revenues. The Japanese government announced a series of fiscal stimulus packages in the 1990s and the late 2000s. These packages were originally motivated by the traditional Keynesian view. However, since the government had set its policy target at a high level, the fiscal stimulus could never achieve the target. The packages, therefore, increased fiscal expenditure during the period, resulting in a huge fiscal deficit. 
In the following analysis, we focus on the role of "stock price targeting” to explain why fiscal expenditure increased so steadily after the burst of the speculative bubble. After a brief summary of Japanese fiscal stimulus packages in the 1990s and 2000s, we present a simple model where the government that is optimistic about stock price and output growth decides its expenditure to minimize the loss function. Unlike previous studies, the loss function includes a deviation of the stock price from its target as a social cost. The resulting government expenditure therefore increases as the stock price declines. We then test whether the resulting government behavior can explain Japan’s fiscal expenditure by using biannual and high-frequency data from the 1990s and the 2000s. The empirical results show that this model can explain Japan’s fiscal expenditure reasonably well, especially in the 1990s. Without the stock price targeting, the total amount of biannual fiscal stimulus from 1992 to 2000 would have been lower by 2.5 trillion yen on average. We also discuss about a possibility that a less effective stimulus policy might have changed the government behavior.

One of the most common ways to test the determinants of fiscal expenditure is to identify when the amount of fiscal expenditure was determined for each fiscal stimulus. Although various alternative methods have been proposed, it is difficult to identify the timing and the amount of fiscal decisions with high-frequency intervals. ${ }^{2}$ In the following analysis, for this identification, we use not only the official information provided by the Japanese Government but also narrative records, such as the Prime Minister's speeches and the cabinet members' announcements. In Japan, the supplementary budget is formulated as an extra budget to stimulate the economy, while the initial budget of general account expenditure is presented in due course every year. It is therefore necessary to identify when the supplementary budget was proposed for each fiscal

\footnotetext{
${ }^{1}$ For example, the front page article in the Nikkei newspaper on August 16, 1992, reported Prime Minister Miyazawa’s commitment to Keidanren, the largest business pressure group in Japan. It mentioned that he committed to a new fiscal package in order to stimulate the stagnated stock market in Japan.

2 See, for example, Blanchard and Perotti (2002) and Ramey (2009) for alternative identification methods. Romer and Romer (2010) suggest the usefulness of using the narrative record for identification.
} 
stimulus. ${ }^{3}$ Fiscal stimulus packages are announced in spring or fall, or both. However, it usually takes a month for the government to make a final decision on the package. During the planning period, the government makes frequent and substantial revisions of the amount. Following Fukuda (2002), we collected narrative records of the revision process based on the articles in three major Japanese newspapers. The collected data is useful to us because each narrative is about an unanticipated shock to the economy. We will then examine whether our model of stock price targeting can track the series of announcements in the 1990s and the 2000s with highfrequency data.

Several previous studies have examined the sources and consequences of the fiscal deficit in Japan. Asako, Ito, and Sakamoto (1991) investigated the rise and fall of the deficit from 1965 to 1990. Fukuda and Teruyama (1994) tested the sustainability of deficits up to the early 1990s, and Ihori, Nakazato, and Kawade (2003) discussed the same issue in the 1990s. Bayoumi (2001) and Miyazaki (2010) investigated the effects of fiscal policy in the 1990s in Japan, using VAR. Ihori, Doi, and Kondo (2001) explored the relationship between political inefficiency and the outcome of the fiscal reconstruction process in the Japanese (national) general account. Doi and Ihori (2002) provided empirical evidence that the lobbying activities of local interest groups exacerbated the deficit in the 1990s. However, few previous studies have focused on the role of “stock price targeting” to explain why fiscal expenditure increased so steadily in the 1990s and the $2000 \mathrm{~s}^{4}$. Interest groups always have an incentive to continue their lobbying activities. Therefore, we need to identify a special reason that explains why lobbying was so active and why it was effective in the specific era. In the following sections, we propose that stock price targeting may provide a plausible explanation of why lobbying was so active in Japan after the burst of the speculative bubble.

\footnotetext{
${ }^{3}$ The initial budget is in principle determined using the previous initial budget to cover regular government expenditure, and usually has little to do with Keynesian policy.

${ }^{4}$ An exceptional study is that of Jaeger and Schuknecht (2007), who showed that boom-bust phases in asset prices tend to exacerbate procyclical policy biases in industrial countries.
} 
This paper proceeds as follows. After summarizing the Japanese fiscal stimulus packages in the 1990s and the 2000s in Section 2, we present a simple model in Section 3 in which the government decides its expenditure to minimize the loss function. Subsequently, we test whether the derived government behavior can explain Japan’s fiscal expenditure, using biannual data in Section 4 and high-frequency data in Section 5. In Section 6, we examine how the effectiveness of fiscal stimuli changed through the 1990s and the 2000s. Section 7 summarizes the main results and lists their implications.

2. Fiscal Stimulus Packages in the 1990s and the Early 2000s

(1) Packages in the 1990s

In this section, we provide an overview of the series of fiscal stimulus packages implemented in the 1990s and early 2000s. Between1992 and 2002, the Japanese government announced fiscal stimulus packages every year except in $1996 .^{5}$ These packages were announced either in spring (i.e., from March to May) or fall (i.e., from August to December), or both. Based on the information provided by the Cabinet Office of the Japanese Government, Table 2 reports the name of each fiscal stimulus package (i.e., the economic countermeasure), the date of its final announcement, and the expenditure. The amount includes not only national government expenditure but also government-supported expenditure such as subsidized loans. ${ }^{6}$ The tax cut is also reported.

The total fiscal expenditure was not specified for some fiscal packages. However, considering the period when it was specified, one of the salient features, as shown in the table, is that the amount increased steadily through the 1990s. This may indicate that Japan's fiscal spending was gradually raised due to political pressure from interest groups in the 1990s.

\footnotetext{
${ }^{5}$ In 1997, the Japanese government tried to implement a Fiscal Structural Reform to reduce the budget deficit. However, in 1998, it stopped the reform, reduced taxes, and increased public investment.
} 
However, it is worth noting that the increase was higher than the amount the government had originally planned in each package. When the Japanese government determined its supplementary budget, it usually took a month from the commencement of planning to reach a final decision. During this planning period, the government was subjected to a series of lobbying activities by interest groups. ${ }^{7}$ Under strong pressure from these groups, the amount of fiscal expenditure was revised substantially in a few days. As a result, in most fiscal packages, the amount finally announced was much larger than that originally budgeted.

Table 3 summarizes to what extent the initial plan was revised in several fiscal stimulus packages in the 1990s. It reports the amounts in the initial, revised, and final announcements as well as the date of the final announcement in each package. It also reports the amounts of tax cut. During the planning period of each fiscal stimulus package, cabinet members and other politicians frequently conveyed their outlook on its total size and related expenditure, either formally or informally. To calculate these amounts, we used narrative information publicized in three Japanese newspapers: Nikkei, Asahi, and Yomiuri. Interestingly, as can be seen in the table, the amount initially announced in most cases was not very different from the final amount of the previous package. However, the amount increased as the revisions progressed. Consequently, in most packages, the amount finally announced was much larger than that originally budgeted. This suggests that the political process to determine the stimulus packages may have been responsible for the steadily increasing fiscal expenditure in the 1990s.

However, this story is not complete until we explain why interest groups were so successful in their lobbying activities during this specific period. Interest groups have always had an incentive to continue their lobbying activities. Therefore, we need to identify a special reason that explains

\footnotetext{
${ }^{6}$ Ideally, government-supported expenditure should be excluded from the amount because it does not increase fiscal deficits directly. Unfortunately, such "pure water" (mamizu) expenditure was not announced in most packages.

${ }^{7}$ For example, on October 12, 1998, Keidanren proposed that a large fiscal package was necessary to stimulate the stagnated Japanese economy. Keizai Doyukai (Japan Association of Corporate Executives)
} 
why lobbying activities were so popular and effective in the 1990s. In the following sections, we propose that the government's stock price targeting may provide a plausible explanation for this.

(2) Packages from 2008 to 2010

The Japanese government implemented no fiscal packages from 2003 to $2007^{8}$. This was partly because the Japanese economy was under recovery during this period. However, Japan’s average growth rate was still one of the lowest among the OECD countries in the 2000s. In contrast, the stock prices, which hit the bottom in April 2003, showed substantial recovery from summer 2003 to summer 2007. ${ }^{9}$ Given the extremely large accumulated fiscal deficit, this may have discouraged the Japanese government from further increasing the fiscal deficit.

However, after the outbreak of the global financial crisis, Japan experienced unprecedented declines in real GDP over the past half century. Stock prices also declined after fall 2007, and the Lehman shock in September 2008 accelerated this decline. Correspondingly, the Japanese government implemented new fiscal stimulus packages in fall 2008, spring 2009, fall 2009, and fall 2010. They follow an agreement made in a G20 meeting that called for coordinated fiscal expansion in member countries.

Table 4 lists the date of the announcements and the fiscal expenditure for six fiscal stimulus packages from 2008 to 2010. It reports the total size, the national government expenditure, and the amount of tax cut for each package. As in Table 3, the narrative information was collected from three newspapers: Nikkei, Asahi, and Yomiuri. Each package of the late 2000s was larger in size than any package of the 1990s. However, unlike the fiscal stimulus packages of the 1990s and early 2000s, these packages were planned and finalized in a relatively short period. More

and the Japan Chamber of Commerce and Industry (JCCI) made similar proposals almost simultaneously. See Nikkei newspaper of April 9, 1998.

${ }^{8}$ Under the Koizumi Administration (April 2001-September 2006), structural reforms was decided upon after acceptance of the report "Structural Reform of the Japanese Economy: Basic Policies for Macroeconomic Development” compiled by the Council on Economic and Fiscal Policy, an advisory council to the prime minister. 
interestingly, revisions were marginal for most packages, and the amount finally announced, in the case of several packages, was not very different from that initially announced.

\section{Why Did the Fiscal Expenditure Increase?}

In the last section, we reviewed the fiscal stimulus packages of the 1990s and the 2000s and showed that the amount of the packages increased substantially throughout the period, especially during the planning phase. The purpose of this section is to present a simple model that may explain why the amount increased so steadily and substantially after the burst of the speculative bubble in Japan. Specifically, we show that implicit stock price targeting may explain the increases in fiscal expenditure that took place during the planning periods. To the extent that the targeted stock prices reflect the fundamental values, the target may not result in a large fiscal deficit. However, if the targeted prices exceed the fundamental values, the government needs to incur extra fiscal expenditure to achieve the target. In the following analysis, we explore the government that has an optimistic view about the stock price fundamentals and the potential output growth.

Consider a simple present discounted value model. In this model, the stock price in period $t$ equals the present discounted value of the current and future expected output. The output in period $t$ is linearly dependent not only on exogenous output but also on the amount of fiscal expenditure in period $t$. We then have the following simple equations:

(1) $S_{\mathrm{t}}=\sum_{i=0}^{\infty} \beta^{i} E_{t} Y_{t+i}$,

(2) $Y_{\mathrm{t}}=y_{\mathrm{t}}+\alpha G_{\mathrm{t}}$

\footnotetext{
${ }^{9}$ For example, the Nikkei 225 Average Index, which fell below 8000 yen in April 2003, rebounded to 14,000 yen in April 2004. It rose to 18,000 yen in February 2007 and remained high until July 2007.
} 
where $S_{\mathrm{t}}=$ stock price, $Y_{\mathrm{t}}=$ output, $y_{\mathrm{t}}=$ exogenous output, $G_{\mathrm{t}}=$ fiscal expenditure, and $\beta=$ discount factor such that $0<\beta<1$. Subscript $t$ denotes time period. $E_{\mathrm{t}}$ is the conditional expectation operator based on the information available in period $t$. The variables are defined as deviations from each trend.

A new feature in the model is that the government does stock price targeting. Under stock price targeting, the government has the following loss function:

(3) $L_{\mathrm{t}} \equiv\left(\Delta Y_{\mathrm{t}}-\Delta Y_{\mathrm{t}}\right)^{2}+\lambda\left(S_{\mathrm{t}}-S^{*}\right)^{2}+f\left(G_{\mathrm{t}}\right)$,

where $\Delta Y_{\mathrm{t}}\left(\equiv Y_{\mathrm{t}}-Y_{\mathrm{t}-1}\right)$ is the change of output, $\Delta Y^{*}{ }_{\mathrm{t}}$ is the targeted change of output, $S^{*}{ }_{\mathrm{t}}$ is the targeted stock price, and $f\left(G_{t}\right)$ is the cost function of implementing the fiscal stimulus. The loss function indicates that the government regards not only the deviations from the targets but also the increases of fiscal expenditure as social costs. We may view implementing the fiscal stimulus as costly because it increases administrative costs and fiscal deficits.

In the following analysis, we define that $f\left(G_{\mathrm{t}}\right) \equiv \omega G_{\mathrm{t}}^{2}+F_{\mathrm{t}}$. This definition implies that the cost of implementing the fiscal stimulus is the sum of a quadratic function of $G_{\mathrm{t}}$ and fixed cost $F_{\mathrm{t}}$. The fixed cost $F_{\mathrm{t}}$ takes a positive value $F$ when $G_{\mathrm{t}}>0$, and zero otherwise. Under the fixed cost, $G_{\mathrm{t}}=$ 0 unless

(4) $\left(\Delta Y_{\mathrm{t}}-\Delta Y^{*}\right)^{2}+\lambda\left(S_{\mathrm{t}}-S^{*}\right)^{2}>F$.

In particular, when both output and stock price are lower than their targeted values, the government implements the fiscal stimulus if and only if Condition (4) holds. In the following analysis, we assume that the post-bubble Japanese economy was in this environment that led to the government's optimistic views about the stock price fundamentals and the potential output 
growth. Then, if and only if Condition (4) holds, the government chooses $G_{\mathrm{t}}$ to minimize the loss $\left(\Delta Y_{\mathrm{t}}-\Delta Y_{\mathrm{t}}\right)^{2}+\lambda\left(S_{\mathrm{t}}-S^{*}{ }_{\mathrm{t}}\right)^{2}+\omega G_{\mathrm{t}}^{2}$. Its first-order condition leads to

(5) $\left(\Delta Y_{\mathrm{t}}-\Delta Y_{\mathrm{t}}^{*}\right)\left(\partial \Delta Y_{\mathrm{t}} / \partial G_{\mathrm{t}}\right)+\lambda\left(S_{\mathrm{t}}-S^{*}{ }_{\mathrm{t}}\right)\left(\partial S_{\mathrm{t}} / \partial G_{\mathrm{t}}\right)+\omega G_{\mathrm{t}}=0$.

Given the expected future outputs, Equations (1) and (2) imply that $\partial S_{\mathrm{t}} / \partial G_{\mathrm{t}}=\partial \Delta Y_{\mathrm{t}} / \partial G_{\mathrm{t}}=\alpha$. We therefore obtain the fiscal expenditure rule as follows:

$$
G_{\mathrm{t}}=-(\lambda \alpha / \omega)\left(S_{\mathrm{t}}-S^{*}{ }_{\mathrm{t}}\right)-(\alpha / \omega)\left(\Delta Y_{\mathrm{t}}-\Delta Y_{\mathrm{t}}{ }\right) \quad \text { when (4) holds, }
$$

(6b) $G_{\mathrm{t}}=0 \quad$ otherwise.

Equations (6a) and (6b) suggest that this rule depends on a threshold value when the government implements fiscal stimulus. When the costs of deviations from target values are below the threshold, the government implements no fiscal stimulus. If and only if the costs exceed the threshold value, the government decides $G_{\mathrm{t}}$ based on Feedback Rule (6a). Under Feedback Rule (6a), the government increases fiscal expenditure as either the stock price or the output growth declines. Since $\lambda$ is the weight of stock price targeting in the loss function, the government responds aggressively when the costs of deviations from the stock price target are high.

\section{Empirical Estimations: A Tobit Model by Using Biannual Data}

(1) The model of the estimation

In the last section, we investigated how stock price targeting will affect the government's behavior and showed that the amount of fiscal expenditure may follow expenditure rules (6a) and (6b). In this section, we will test how well the expenditure rule can account for the Japanese 
government's behavior in the 1990s and the 2000s. A key feature in estimating the expenditure rule is that $G_{\mathrm{t}}=0$ unless Condition (4) holds. We thus estimate a censored regression model where an underlying latent variable is determined by a feedback rule but the dependent variable is observed only if it is above some cutoff level.

Specifically, we estimate the following Tobit model, which expresses the observed level of fiscal expenditure $G_{\mathrm{t}}$ in terms of an underlying latent variable $g_{\mathrm{t}}$ :

(7) $g_{\mathrm{t}}=$ constant $-\delta\left(S_{\mathrm{t}}-S^{*}{ }_{\mathrm{t}}\right)-\phi \Delta Y_{\mathrm{t}}+X_{\mathrm{t}}$,

(8) $G_{\mathrm{t}}=g_{\mathrm{t}} \quad$ if $g_{\mathrm{t}}>0$, $=0 \quad$ otherwise.

Equation (7) indicates that the underlying latent variable follows an extended version of Feedback Rule (6a). In Equation (7), we allow that the targeted stock price $S{ }^{*}$ is time-varying. However, to control for other time-varying factors, some regressions include auxiliary variables $X_{\mathrm{t}}$ 's as explanatory variables. The auxiliary variables are the level of output, the "Koizumi-Abe" dummy, and the "fall” dummy. The "Koizumi-Abe” dummy is a dummy that takes one during the Koizumi-Abe administration (spring 2001 to spring 2008) and zero otherwise. The dummy allows for the fact that Prime Minister Koizumi and his successor, Prime Minister Abe, worked on the fiscal reconstruction more seriously than the other administrations. ${ }^{10}$ The "fall" dummy is a dummy that takes one in fall and zero otherwise.

The data are biannual (spring and fall in each year). We use biannual data because the fiscal stimulus packages, if any, were announced in either spring or fall, or both ${ }^{11}$. Because of data availability, the total fiscal expenditure in each fiscal stimulus package — which includes both

\footnotetext{
${ }^{10}$ See, for example, Fukuda and Nakamura, (2011) on how the Japanese economy recovered during the period.

${ }^{11}$ The exceptions were in fall 2001 and fall 2010, when the government announced multiple stimulus packages. In our estimations, we summed up the amount of fiscal expenditures for these packages.
} 
national government and government-supported expenditure-is considered. However, we use the total amount, either with or without tax cut. When the total expenditure announced was only an approximate amount, we used this for the estimations. Because of the censored model, we set the dependent variable as zero when the government announced no fiscal stimulus package.

The sample period is from fall 1991 to fall 2010. Unit of the fiscal expenditure is trillion yen. In a base-line Tobit model, we use the total size that was finally decided for each package as the fiscal expenditure. To check the robustness, we also estimate a Tobit model, replacing this size by the total size that was initially planned. The stock price $S_{\mathrm{t}}$ is the $\log$ of the Nikkei 225

Average Index. We used the logged value because we penalize excess volatility of stock prices. To avoid simultaneous bias, we use the February data for the spring price and the August data for the fall price. The output $Y_{\mathrm{t}}$ is the industrial production index - that of February for the spring data and August for the fall data. We used the growth rate of output for $\Delta Y_{t}$, which equals the change in the logged industrial production index from August to February for the spring data and that from February to August for the fall data.

Concerning the targeted stock price, we suppose that the government had an optimistic view about the recovery of the stock price. Specifically, we assume that the government set the stock price in February 1992 as the target from 1992 to 2000. Japan’s stock price, which dropped sharply in 1990 and 1991, was cyclical from 1992 to 2000. The targeted stock price was close to the upper bound of the cyclical movement during this period. However, the Japanese economy had two structural changes in the 2000s: the structural and fiscal reforms under Prime Minister Koizumi and the global financial crisis. To allow for these structural changes, we assume that the government changed the stock price target twice in the 2000s: at the beginning of the Koizumi administration and at the beginning of the global financial crisis. We use the stock price in February 2001 as the target from spring 2001 to spring 2008. The targeted price was close to the initial stock price when Prime Minister Koizumi commenced a series of structural and fiscal reforms in Japan. We also use the stock price in August 2007 as the target for fall 2008 to fall 
2010. The targeted price was a proxy for the two-year average of the stock price before the global financial crisis. We assume that the government tried to recover the stock price to this precrisis level during the global financial crisis.

Since we use the Nikkei 225 Average Index for $S_{t}$, the assumed targeted stock prices imply that $S^{*}{ }_{\mathrm{t}}=21412.57$ yen from spring 1992 to fall $2000, S^{*}=13266.27$ yen from spring 2001 to spring 2008, and $S^{*}=16460.95$ yen from fall 2008 to fall 2010 in the following analysis. The choice of targeted stock prices is arbitrary. However, this choice will affect the constant term and the coefficient of the "Koizumi-Abe" dummy rather than the coefficient of the stock price in the following estimation.

\section{(2) Estimation results}

Table 5 summarizes the regression results. It reports estimations with and without the lagged dependent variable, and estimations with and without the level of output. Our estimation results are essentially the same regardless of the model specifications. Neither the constant term nor the coefficient of the lagged dependent variable was significant in any case. In contrast, the coefficient of the fall dummy was positive, while the coefficient of the "Koizumi-Abe" dummy was negative in all cases. Although their significance levels are marginal, they suggest that the Japanese government tended to have larger fiscal stimulus packages in fall and smaller fiscal stimulus packages under the Koizumi-Abe administration.

The coefficients of the stock price deviation from the target and the output growth rate were significantly negative in all cases. This supports our hypothesis that not only the output growth targeting but also the stock price targeting are relevant in determining the fiscal expenditure. In contrast, the coefficient of the level of industrial production index was positive but insignificant. Comparing the estimated coefficients for the two alternative dependent variables, both the logged stock price index and the growth rate of output had larger coefficients when we used the final amount for the dependent variable. This implies that both stock price targeting and output growth 
targeting, which were relevant in determining the initially planned amount, might have additional importance in revising the amount in the planning periods.

Regarding the quantitative impacts on fiscal expenditure, the estimated coefficient of the stock price deviation from the target was around -27 for the final amount and around -22 for the initial amount, as shown in the table. This indicates that a 1\% decline in the Nikkei 225 average index increased the biannual fiscal expenditure by 0.18 trillion yen for the final amount and by 0.096 trillion yen for the initial amount. Note that the Nikkei 225 Average Index from fall 1992 to fall 2000 was, on average, approximately 20\% lower than that in fall 1991. This implies that, given the assumed targeted level, stock price targeting explains 2.62 trillion yen of biannual fiscal expenditure for the final amount and 2.13 trillion yen for the initial amount from fall 1992 to fall 2000. This amount nearly equals to $40 \%$ of biannual average of the stimulus package fiscal expenditure during the same period: 6.68 trillion yen for the final amount and 5.37 trillion yen for the initial amount. The substantial stock price decline in the 1990s may have resulted in the incredibly large fiscal deficit through stock price targeting.

However, stock price targeting cannot explain the highly restricted fiscal expenditure during the Koizumi-Abe administration. The Nikkei 225 Average Index, which had recovered substantially after spring 2003, was still lower than that between spring 2001 and the mid-2000s. This suggests that, given the assumed targeted level, the Koizumi-Abe administration may not have used stock price targeting. In addition, stock price targeting explains only some of the dramatic increases in fiscal expenditure during the global financial crisis. The Nikkei 225 Average Index in spring 2009 dropped by nearly 50\% from spring 2007. Given the assumed targeted level, our estimated coefficient predicts a final amount of 8.13 trillion yen and an initial amount of 6.62 trillion yen of fiscal expenditure in spring 2009. However, these amounts are much lower than the actual fiscal expenditure in spring 2009: a final amount of 56.8 trillion yen and an initial amount 56 trillion. 
In contrast, the estimated coefficient of output growth was around -94 for the final amount and around -91 for the initial amount. This indicates that when the difference between actual and targeted biannual output growth rates is $-1 \%$, the biannual fiscal expenditure increases by 0.94 trillion yen for the final amount and by 0.91 trillion yen for the initial amount. The marginal impacts are higher than those of the logged stock price. However, the biannual growth rate of the industrial production index was, on average, 0.24\% from fall 1992 to fall 2000. This indicates that unless the government had an extremely large output growth target, the difference between actual and targeted output growth rates cannot explain the large fiscal deficit in the 1990s. However, the biannual growth rate of the industrial production index was -6\% in fall 2008 and 31\% in spring 2009. The dramatic output decline during the global financial crisis implies that output growth targeting may explain the dramatic increases in fiscal expenditure in fall 2008 and spring 2009.

Figures 3-(1) and 3-(2) depict the actual biannual fiscal expenditure and its predicted amount by the stock price targeting and the output growth targeting from fall 1992 to fall 2000 and from spring 2001 to fall 2010. Since the actual biannual fiscal expenditure is volatile in each stimulus package, we took its three-period moving average in the figures. ${ }^{12}$ We computed the predicted amount by multiplying the estimated coefficients and deviations from the target. In the figures, "prediction 1" is the predicted amount only by deviations from the stock price target and "prediction 2" is the predicted amount by deviations from both the stock price target and the output growth target. In making the prediction, we assumed that the targeted biannual annual output growth rate is $1 \%$ throughout the period. Figure 3-(1) indicates that the predicted amount, especially prediction 1, accounts for significant part of the actual expenditure in the 1990s. However, Figure 3-(2) indicates that the predicted amount cannot account for the restricted expenditure and most of the dramatically increased expenditure during the global crisis. 


\section{Determinants of Fiscal Expenditure During the Planning Periods}

In the last section, we explored the determinants of fiscal expenditure by using biannual data, and show that stock price targeting was an important determinant of fiscal expenditure, especially in the 1990s. However, as was shown in Section 2, the amount of fiscal expenditure for each package changed frequently during the planning period. The effective changes in expenditure occurred in a very short period, especially in the 1990s. The purpose of this subsection is to explore what changed the fiscal expenditure so quickly during the short planning periods. In the regressions, the dependent variable is the narrative amounts of fiscal expenditure that were summarized in Tables 3 and 4 . This high-frequency data changed in a few days during the planning period. When only the approximate amount was announced, we used this for the estimations.

The sample periods are from 1992 to 2000 and from 2008 to $2010 .^{13}$ Unit of the fiscal expenditure is trillion yen. Because of the limited availability of narrative amounts, we use different types of fiscal expenditure for the two alternative sample periods: total size (national government expenditure plus government-supported expenditure) for the period from 1992 to 2000 and national government expenditure for the period from 2008 to 2010 . Because of data availability, we estimated Equation (7) using ordinary least squares from the pooled data for the period 1992 to 2000 or 2008 to 2010. In either case, we estimated Equation (7) by using the amount of fiscal expenditure, either with or without tax cut. The stock price $S_{t}$ is the log of the Nikkei 225 Average Index at closing time (3 PM) on the day before the announcement. As in the last section, the targeted stock price for the period 1992 to 2000 is the February 1992 price, and that for the period 2008 to 2010 is the August 2007 price. Because the announced fiscal expenditure had serial correlations in the high-frequency data, the amount in the previous announcement is included as the lagged dependent variable.

\footnotetext{
${ }^{12}$ Specifically, we calculated the moving average of $\mathrm{x}_{\mathrm{t}}$ by $\mathrm{x}_{\mathrm{t}} / 2+\left(\mathrm{x}_{\mathrm{t}-1}+\mathrm{x}_{\mathrm{t}+1}\right) / 4$.
} 
One problem with using high-frequency data is that the relevant output data are not available. However, several output data were usually publicized by statistical agencies during the sample periods. We thus include a good news dummy and a bad news dummy in the regression. A good news dummy takes the value of one when the improved output data was publicized before the fiscal announcement and zero otherwise, while a bad news dummy takes the value of one when the deteriorated output data was publicized and zero otherwise. In addition to the news dummies, we also include the daily change of the dollar-yen exchange rates as an additional explanatory variable for the estimation from 2008 to 2010. This follows the fact that the Japanese yen appreciation was an important policy agenda after the global financial crisis. To capture the effects of seasonality, we include a "fall” dummy that takes the value of one for the packages in fall and zero otherwise. We also include an "initial" dummy that takes the value of one in the case of the initial announcement for each package and zero otherwise.

Table 6-(1) summarizes the regression results for the period 1992 to 2000. The amount in the latest announcement took a significantly positive sign, while the fall dummy took a significantly negative sign in the high-frequency data. The initial dummy was significantly negative in all cases, suggesting that the initial announcement in each package was moderate. These features cannot be observed in the biannual data. However, as in the biannual data, the coefficient of the logged stock price index is negative even if we use the high-frequency data. Even the highfrequency data support our hypothesis that stock price targeting is relevant in determining fiscal expenditure.

The instantaneous impact of the stock price deviation from the target was smaller than that observed in the biannual data. In particular, it was less significant when the tax cut was excluded from the total size. However, when the tax cut was included, the impact, at around -12, was highly significant. We also need to note that the coefficient of the lagged dependent variable was

\footnotetext{
${ }^{13}$ We do not include the fiscal stimulus packages of 2001 and 2002 because there was no explicit revision when planning these packages.
} 
0.52. This suggests that, taking into account the lag structure, the stock price targeting still accounts for the fiscal expenditure when revising the amount of expenditure in each fiscal package. In contrast, the two news dummies had asymmetric effects on fiscal expenditure. The government had asymmetric responses to the macro news, depending on whether the news was positive or negative. However, the absolute values of their estimated coefficients were small, so that their quantitative impacts were limited.

Table 6-(2) summarizes the regression results for the period from 2008 to 2010. Because of the limited samples in each package, no coefficient of the news dummies was significant, and the coefficients sometimes took wrong signs. However, as in the 1990s, the fall dummy and the initial dummy took significantly negative signs, while the amount in the latest announcement took a significantly positive sign. More importantly, the coefficient of the stock price deviation from the target was significantly negative, and its absolute value was higher than that observed for the period 1992 to 2000. This result suggests that when revising the amount of expenditure in each fiscal package, the government responded more quickly during the global financial crisis than in the 1990s. In addition, the change in the yen-dollar exchange rates took a significantly negative sign. The government tended to increase its expenditure when the Japanese Yen appreciated against the US dollar during the global financial crisis.

In terms of expenditure size, the fiscal expansions in the late 2000s were larger than those in the 1990s and the early 2000s. The accumulated government liabilities, which were temporarily stabilized from 2006 to 2007, surged dramatically after fall 2008. Our empirical results suggest that stock price targeting was responsible for the sudden, dramatic fiscal expansions in the late 2000s. The Nikkei Average Index, which was over 18,000 yen in July 2007, fell below 10,000 yen after the Lehman shock and was almost 7,000 yen in March 2008. Fiscal expansions were inevitable from 2008 to 2010 during the stock market crash caused by the global financial crisis.

6. Effects of the Fiscal Stimulus on the Stock Prices 
Until the previous section, we used the implicit assumption that the fiscal stimulus is effective in increasing the output. Although this assumption follows the classical Keynesian view, it is unlikely that the fiscal stimulus packages were similarly effective through the 1990s and 2000s. Under stock price targeting, the government needs to expand fiscal expenditure when the stock price is lower than its targeted level. However, less effective fiscal stimuli may discourage the government from taking the action. The purpose of this section is to examine how the effectiveness of the fiscal stimuli changed through the 1990s and the 2000s.

We estimate the following equation:

(9) $\Delta S_{\mathrm{t}}=$ constant $+\eta G_{\mathrm{t}}+v\left(Y_{\mathrm{t}}-E_{\mathrm{t}-1} Y_{\mathrm{t}}\right)$

where $\Delta S_{\mathrm{t}} \equiv S_{\mathrm{t}}-S_{\mathrm{t}-1}$, and $E_{\mathrm{t}-1} Y_{\mathrm{t}}$ is expected to be $Y_{\mathrm{t}}$ based on the information at t-1. In Equation (9), the coefficient $\eta$ captures the effectiveness of the fiscal expenditure. We used intra-day data from the Nikkei 225 Average Index (at 12:45 PM Tokyo Time and at 3 PM Tokyo Time) for the stock prices. We estimate Equation (9) separately for 14 fiscal stimulus packages in the 1990s and the 2000s.

As explanatory variables, we use dummy variables as proxies for $G_{\mathrm{t}}$ and $Y_{\mathrm{t}}-E_{\mathrm{t}-1} Y_{\mathrm{t}}$. For the fiscal expenditure shock $G_{\mathrm{t}}$, we use a fiscal policy dummy that takes the value of one when the initial, revised, or final announcement was made for each package and zero otherwise. To the extent that its coefficient is significantly positive, we may conclude that the fiscal stimulus was effective. For the unexpected output shock $Y_{\mathrm{t}}-E_{\mathrm{t}-1} Y_{\mathrm{t}}$, we use three dummy variables: a good output news dummy, a bad output news dummy, and a dummy of monetary expansion. ${ }^{14}$ The good news dummy takes one when improved macro data were publicized and zero otherwise,

\footnotetext{
${ }^{14}$ A good output news dummy takes one when the macro statistics (Quarterly Estimates of GDP, Indices of Industrial Production, Orders Received for Machinery, and TANKAN) showed a higher value than the average private sector's forecast and zero otherwise. A bad output news dummy takes one when the macro statistics showed a lower value than the average private sector's forecast and zero otherwise.
} 
while the bad news dummy takes one when deteriorated macro data was publicized and zero otherwise. The dummy of monetary expansion takes one when the Bank of Japan announced monetary expansions and zero otherwise. We also include the change in the overnight call rate as an explanatory variable.

Table 7 summarizes the estimation results. Throughout the periods, the good output news dummies and dummies of monetary expansion tended to have positive effects, while the bad output news dummies had negative effects. However, the dummies that took significant signs were limited. The overnight call rate also had a significant effect on a few packages.

In the 1990s, the coefficient of the fiscal policy dummy was significantly positive in the stimulus packages in fall 1992, spring 1993, and spring 1998. However, the dummy did not take a significantly positive sign in the other packages. This indicates that the fiscal stimulus was effective only when the government had not implemented a stimulus package in the previous few years. In other words, the stimulus packages became less effective when the government had been implementing them for several consecutive years in the 1990s. Similarly, in the late 2000s, the fiscal policy dummy was positive in fall 2009. However, in the other four packages, the dummy was not significant, although it mostly took positive signs. These results imply that the large-scale fiscal expansions in the late 2000s were effective to some extent but that their role was limited to stimulating the stock markets during this period.

Under stock price targeting, it is ambiguous how less effective fiscal stimuli affect the government behavior. The stock price tends to show larger deviation from its targeted level under less effective fiscal stimuli. However, parameter $\alpha$ in equation (6a) declines when fiscal stimuli are less effective. The effect on the further fiscal expenditure thus depends on which is dominant. We need detailed investigation to derive definitive answers. But substantial increases in fiscal deficits in the late 1990s might be attributable to larger deviation from its targeted level under less effective fiscal stimuli. In contrast, the restricted fiscal expenditure under the 
Koizumi-Abe administration might be attributable to decline of parameter $\alpha$ under less effective fiscal stimuli.

\section{Concluding Remarks}

In this paper, we explained why Japan increased its fiscal deficit so dramatically in the 1990s and the 2000s. We investigated the role of "stock price targeting" in the series of stimulus fiscal packages in Japan. After presenting a simple model to describe the government's behavior, we tested whether this model explained Japan's fiscal expenditure in the 1990s and the 2000s.

Although there remain several unexplained features, the empirical results could track the Japan's fiscal expenditure reasonably well, especially in the 1990s.

Stock prices are one of the key variables in macroeconomics. Unlike other macroeconomic variables, we can observe their movements with high frequency. We therefore tend to pay more attention to the stock prices than to other macro variables when making a policy decision on a daily basis. However, unlike other macroeconomic variables, stock prices are likely to deviate substantially from their fundamental values. Therefore, the policymaker faces a dilemma on whether to use asset prices as a policy target. The Japanese experience discussed in this paper provides a useful lesson for using the stock price as a policy target.

After the global financial crisis, renewed attention has been paid to the role of discretionary fiscal policy all over the world (for example, Feldstein [2009]). This focus includes the effectiveness of fiscal spending (for example, Barro and Redlick [2009]) and the interaction of monetary and fiscal policy (for example, Davig and Leeper [2009]). However, discretionary fiscal policies need to be evaluated not only for their short-run benefits but also for their potential long-run costs. The Japanese lesson suggests that discretionary fiscal policy under stock price targeting may have resulted in serious fiscal deficits in the long run. 


\section{References}

Asako, K., T. Ito, and K. Sakamoto, (1991), “The Rise and Fall of Deficit in Japan, 1965-1990,” Journal of the Japanese and International Economies, 5, pp.451-72.

Barro, R., and C. Redlick, (2009), “Macroeconomic Effect from Government Purchases and Taxes,” NBER Working Paper No. 15369.

Bayoumi, T., (2001), “The Morning After: Explaining the Slowdown in Japanese Growth in the 1990s,” Journal of International Economics, 53(2), pp.241-59.

Blanchard, O., and R. Perotti, (2002), “An Empirical Characterization of the Dynamic Effects of Changes in Government Spending and Taxes on Output,” Quarterly Journal of Economics, 117(4), pp.1329-1368.

Doi, T., and T. Ihori, (2002), “Fiscal Reconstruction and Local Interest Groups in Japan,” Journal of the Japanese and International Economies, 16 (4), pp.492-511.

Davig, T., and E. Leeper, (2009), “Monetary-Fiscal Policy Interactions and Fiscal Stimulus,” NBER Working Paper No. 15133.

Feldstein, M., (2009), “Rethinking the Role of Fiscal Policy,” American Economic Review, 99(2), pp.556-559.

Fukuda, S., (2002), “What Made Fiscal Deficits so Large in Japan? An Implication from News in the 1990s (in Japanese),” Financial Review, 63, pp.83-106.

Fukuda, S., and H. Teruyama, (1994), “The Sustainability of Budget Deficits in Japan,” Hitotsubashi Journal of Economics, 35, pp.109-119.

Fukuda, S., and J. Nakamura, (2011), "Why Did "Zombie" Firms Recover in Japan?" The World Economy, 34(7), pp.1124-1137.

Ihori, T., T. Doi, and H. Kondo, (2001), “Japanese Fiscal Reform: Fiscal Reconstruction and Fiscal Policy,” Japan and the World Economy, 13, pp.351-70. 
Ihori, T., T. Nakazato, and M. Kawade, (2003), “Japan’s Fiscal Policies in the 1990s,” The World Economy, 26, pp.325-38.

Jaeger, A., and L. Schuknecht, (2007), “Boom-Bust Phases in Asset Prices and Fiscal Policy Behavior,” Emerging Markets Finance and Trade, 43(6), pp.45-66.

Miyazaki, T., (2010), “The Effects of Fiscal Policy in the 1990s in Japan: A VAR Analysis with Event Studies,” Japan and the World Economy, 22(2), pp.80-87.

Ramey, V., (2009), “Identifying Government Spending Shocks: It’s All in the Timing,” NBER Working Paper No. 15464.

Romer, C. D., and D. H. Romer, (2010), “The Macroeconomic Effects of Tax Changes: Estimates Based on a New Measure of Fiscal Shocks,” American Economic Review, 100(3), pp.763-801. 
Table 1. Average Annual Growth Rates in Selected OECD Countries

Unit: \%

\begin{tabular}{|c|c|c|c|c|c|c|}
\hline & $\begin{array}{l}\text { OECD } \\
\text { avg. }\end{array}$ & USA & Japan & France & Italy & Switzerland \\
\hline 1990-2000 & 2.56 & 3.19 & 1.49 & 1.85 & 1.41 & 1.09 \\
\hline 2000-2007 & 2.60 & 2.60 & 1.72 & 2.12 & 1.47 & 2.18 \\
\hline 1990-2007 & 2.57 & 2.92 & 1.59 & 1.97 & 1.44 & 1.57 \\
\hline
\end{tabular}

Source: OECD, National Account Statistics.

Table 2. Fiscal Stimulus Packages in the 1990s and 2000s

\begin{tabular}{|c|c|c|c|}
\hline Name of Economic Countermeasures & Date & Total size & Excluding tax cut \\
\hline Emergency Economic Measures & $1992 / 3 / 31$ & $\mathrm{NA}$ & \multirow{8}{*}{ 9,780 billion yen } \\
\hline Comprehensive Economic Stimulus Measures & $1992 / 8 / 28$ & 10,700 billion yen & \\
\hline Comprehensive Economic Measures & $1993 / 4 / 13$ & 13,200 billion yen & \\
\hline Emergency Economic Measures & $1993 / 9 / 16$ & 6,150 billion yen & \\
\hline Comprehensive Package of Economic Measures & $1994 / 2 / 8$ & 15,250 billion yen & \\
\hline Emergency Economic Countermeasures to Cope with the Yen & $1995 / 4 / 14$ & & \\
\hline Economic Measures & $1995 / 9 / 20$ & 14,220 billion yen & \\
\hline Emergent Economic Policy Package Reforming Japan for the 21st & $1997 / 11 / 18$ & NA & \\
\hline Comprehensive Economic Measures & $1998 / 4 / 24$ & 16,650 billion yen & \multirow{9}{*}{$\begin{array}{l}12,650 \text { billion yen } \\
17,900 \text { billion yen }\end{array}$} \\
\hline Emergency Economic Package & $1998 / 11 / 16$ & 23,900 billion yen & \\
\hline Measures for the Rebirth of the Japanese economy & $1999 / 11 / 11$ & about 18 trillion yen & \\
\hline Policy Package for New Econ. Develop. Measures for the Rebirth of & $2000 / 10 / 19$ & about 11 trillion yen & \\
\hline Emergency Economic Package & $2001 / 4 / 6$ & NA & \\
\hline Front-Loaded Reform Program & $2001 / 10 / 26$ & about 5.8 trillion yen & \\
\hline Immediate Economic Action Package & $2001 / 12 / 14$ & about 4.1 trillion yen & \\
\hline Comprehensive Measures to Accelerate Reforms & $2002 / 10 / 30$ & NA & \\
\hline Program to Accelerate Reforms & $2002 / 12 / 12$ & about 4.4 trillion yen & \\
\hline Comprehensive Immediate Policy Package -Easing Public Anxiety- & $2008 / 8 / 29$ & about 11.7 trillion yen & \multirow{7}{*}{ about 24.9 trillion } \\
\hline Measures to Counter Difficulties in People's Daily Lives & $2008 / 10 / 30$ & about 26.9 trillion yen & \\
\hline Immediate Policy Package to Safeguard People’s Daily Lives & $2008 / 12 / 19$ & about 43 trillion yen & \\
\hline Countermeasures to Address the Economic Crisis & $2009 / 4 / 10$ & about 56.8 trillion yen & \\
\hline Emergency Economic Countermeasures for Future Growth and Security & $2009 / 12 / 8$ & about 24.4 trillion yen & \\
\hline Three-Step Economic Measures for the Realization of the New Growth & $2010 / 9 / 10$ & about 9.8 trillion yen & \\
\hline $\begin{array}{l}\text { Comprehensive Emergency Economic Measures In Response to the Yen's } \\
\text { Appreciation and Deflation }\end{array}$ & $2010 / 10 / 8$ & about 21.1 trillion yen & \\
\hline
\end{tabular}

Note 1) Total size on December 19, 2008, includes that on October 30, 2008.

2) "NA" means that the specific amount was not announced.

Source: Cabinet Office, Japanese Government. 
Table 3. Changes in the Narrative Amount during Each Planning Period

92.8.28 Morning: Comprehensive Economic Stimulus Measures

\begin{tabular}{|lll|}
\hline & Total size & Source of the annoucement \\
\hline 92.8 .7 & $6-7$ trillion & LDP Policy Research Council \\
92.8 .21 & $7-8$ trillion & gov. skeleton \\
92.8 .25 & 8 trillion and over & LDP plan \\
92.8 .26 & 9 trillion and over & gov. draft \\
92.8 .28 & 10.7 trillion & LDP final decision \\
\hline
\end{tabular}

93.4.13 Morning: Comprehensive Economic Measures

\begin{tabular}{|lll|}
\hline & Total size & Source of the annoucement \\
\hline 93.3 .16 & 10.7 trillion and over & LDP 4 executive members \\
93.4 .2 & about 12 trillion & gov. outlook \\
93.4 .13 & 13.2 trillion & gov. final decision \\
\hline
\end{tabular}

93.9.16 Evening: Emergency Economic Measures

\begin{tabular}{|lll|}
\hline & Total size & Source of the annoucement \\
\hline 93.9 .10 & 5 trillion and over & gov. skeleton \\
93.9 .16 & 6.15 trillion & gov. final decision \\
\hline
\end{tabular}

94.2.8 Afternoon: Comprehensive Package of Economic Measures

\begin{tabular}{|llll|}
\hline & $\begin{array}{l}\text { Total size } \\
\text { including tax cut }\end{array}$ & $\begin{array}{l}\text { The amount } \\
\text { of tax cut }\end{array}$ & $\begin{array}{l}\text { Source of the } \\
\text { annoucement }\end{array}$ \\
\hline 94.1 .7 & 7 trillion and over & 0 & gov. party skeleton \\
94.1 .25 & 13.2 trillion & $6-7$ trillion & gov. skeleton \\
94.1 .28 & 15 trillion and over & $6-7$ trillion & gov. outlook \\
94.2 .3 & 15.1 trillion & 5.3 trillion & gov. outlook \\
94.2 .8 & 15.25 trillion & 5.47 trillion & gov. final decision \\
\hline
\end{tabular}

95.9.20 Noon: Economic Measures

\begin{tabular}{|lll|}
\hline & Total size & Source of the annoucement \\
\hline 95.9 .13 & 10 trillion and over & gov. skeleton \\
95.9 .18 & $11-12$ trillion & gov. and coalition parties outlook \\
95.9 .20 & 14.22 trillion & gov. final decision \\
\hline
\end{tabular}


Table 3. Changes in the Narrative Amount during Each Planning Period (continued)

98.4.24 Evening: Comprehensive Economic Measures

\begin{tabular}{|llll|}
\hline & $\begin{array}{l}\text { Total size } \\
\text { including tax cut }\end{array}$ & $\begin{array}{l}\text { Special } \\
\text { tax cut }\end{array}$ & $\begin{array}{l}\text { Source of the } \\
\text { annoucement }\end{array}$ \\
\hline 98.3 .25 & 12 trillion and over & 0 & gov. and LDP plan \\
98.3 .26 & 16 trillion and over & 0 & coalition parties guideline \\
98.3 .29 & 16 trillion and over & 3-4 trillion & gov. and LDP plan \\
98.4 .9 & 16 trillion and over & 4 trillion & prime minister \\
98.4 .24 & 16.65 trillion & 4 trillion & gov. final decision \\
\hline
\end{tabular}

98.11.16 Morning: Emergency Economic Package

\begin{tabular}{|llll|}
\hline & $\begin{array}{l}\text { Total size } \\
\text { including tax cut }\end{array}$ & \multicolumn{1}{c|}{$\begin{array}{c}\text { Permanent } \\
\text { tax cut }\end{array}$} & $\begin{array}{l}\text { Source of the } \\
\text { annoucement }\end{array}$ \\
\hline 98.10 .6 morning & 17 trillion and over & about 7 trillion & prime minister \\
98.11 .12 & 20 trillion and over & about 7 trillion & gov. outlook \\
98.11 .16 Morning: 23.9 trillion & 6 trillion & gov. final decision \\
\hline
\end{tabular}

99.11.11 Morning: Measures for the Rebirth of the Japanese economy

\begin{tabular}{|lll|}
\hline & Total size & Source of the annoucement \\
\hline 99.10 .8 morning & 10 trillion and over & prime minister's plan \\
99.10 .22 & $11-12$ trillion & gov. and LDP skeleton \\
99.11 .3 & 15 trillion & gov. outlook \\
99.11 .10 & 17 trillion & news report on gov. final decision \\
99.11 .11 morning & 18 trillion & gov. final decision \\
\hline
\end{tabular}

2000.10.19 morning: Policy Package for New Economic Development Measures for the Rebirth of Japan

\begin{tabular}{|lll|}
\hline & Total size & Source of the annoucement \\
\hline 00.10 .13 & 10 tril lon and over & gov. plan \\
00.10 .17 morning & about 11 trillion & finance minister \\
00.10 .19 morning & about 11 trillion & final decision by cabinet members \\
\hline
\end{tabular}

Sources: Cabinet Office, Japanese Government, Nikkei Newspaper, Asahi Newspaper, and Yomiuri Newspaper. 
Table 4. Changes in the Narrative Amount for Each Stimulus Package in 2008 and 2009

Comprehensive Immediate Policy Package -Easing Public Anxiety- (2008/8/29)

\begin{tabular}{|l|lll|}
\hline & Total size & National gov. expenditurı Source of the annoucement \\
\hline $2008 / 8 / 17$ & n.a. & $2-3$ trillion & LDP politician \\
$2008 / 8 / 22$ & about 8 trillion & n.a. & gov. outlook \\
$2008 / 8 / 28$ & about 10 trillion & about 1 trillion & gov. skeleton \\
$2008 / 8 / 29$ morning & about 11 trillion & n.a. & agreement between gov. and LDP \\
$2008 / 8 / 29$ & about 11.7 trillion & 2 trillion & gov. final decision \\
\hline
\end{tabular}

Measures to Counter Difficulties in People's Daily Lives (2008/10/30)

\begin{tabular}{|l|llll|}
\hline & Total size & National gov. expenditurı cash handout & Source of the annoucement \\
\hline $2008 / 10 / 22$ & n.a. & about 5 trillion & 2 trillion & gov. skeleton \\
$2008 / 10 / 29$ & $20-25$ trillion & about 5 trillion & 2 trillion & government \\
$2008 / 10 / 30$ & about 26.9 trillion yen & about 5 trillion & 2 trillion & gov. final decision \\
\hline
\end{tabular}

Immediate Policy Package to Safeguard People’s Daily Lives (2008/12/19)

\begin{tabular}{|l|lll|}
\hline & Total size & National gov. expenditur Source of the annoucement \\
\hline $2008 / 12 / 12$ & about 23 trillion & about 10 trillion & prime minister \\
$2008 / 12 / 19$ mornin & about 43 trillion & n.a. & cabinet meeting \\
$2008 / 12 / 19$ & about 43 trillion & about 10 trillion & gov. final decision \\
\hline
\end{tabular}

Countermeasures to Address the Economic Crisis (2009/4/10)

\begin{tabular}{|l|lll|}
\hline & Total size & National gov. expenditur Source of the annoucement \\
\hline $2009 / 3 / 31$ & n.a. & 10 trillion and over & prime minister \\
$2009 / 4 / 4$ & n.a. & more than 10 trillion & gov. outlook \\
$2009 / 4 / 6$ & n.a. & $11-14$ trillion & gov. internal approval \\
$2009 / 4 / 8$ & 56 trillion and over & about 15 trillion & gov. and coalition parties agreement \\
$2009 / 4 / 9$ moming & 56.8 trillion & 15.4 trillion & LDP approval \\
$2009 / 4 / 10$ & 56.8 trillion & 15.4 trillion & gov. final decision \\
\hline
\end{tabular}

Emergency Economic Countermeasures for Future Growth and Security (2009/12/8)

\begin{tabular}{|l|lll|}
\hline & Total size & \multicolumn{1}{l|}{ National gov. expenditur Source of the annoucement } \\
\hline $2009 / 11 / 27$ & n.a. & 2.7 trillion & gov. initial outlook \\
$2009 / 11 / 30$ mornin & 10 trillion and over & 2.7 trillion and over & prime minister \\
$2009 / 12 / 1$ & over 20 trillion & about 4 trillion & working group \\
$2009 / 12 / 2$ & much larger than 10 tril. about 4 trillion & working group \\
$2009 / 12 / 2$ & about 20 trillion & about 4 trillion & gov. guideline \\
$2009 / 12 / 3$ & about 24 trillion & about 4 trillion & working group (final) \\
$2009 / 12 / 4$ morning & about 24.3 trillion & n.a. & cabinet amendment \\
$2009 / 12 / 7$ & n.a. & about 4 trillion and over & cabinet amendment \\
$2009 / 12 / 8$ & about 24.4 trillion & 4.2 trillion & cabinet final decision \\
\hline
\end{tabular}

Comprehensive Emergency Economic Measures In Response to the Yen's Appreciation and Deflation (2010/10/8)

\begin{tabular}{|l|lll|}
\hline & Total size & National gov. expenditur Source of the annoucement \\
\hline $2010 / 9 / 25$ & n.a. & $3.8-4.6$ trillion & gov. initial decision \\
$2010 / 9 / 27$ & n.a. & 4.5 trillion & top meeting between gov. and DPJ \\
$2010 / 10 / 1$ & n.a. & 4.8 trillion & gov. and DPJ interrim decision \\
$2010 / 10 / 6$ & n.a. & about 5 trillion & proposal of DPJ to gov. \\
$2010 / 10 / 7$ evening & n.a. & 5.05 trillion & DPJ and People's New Party \\
$2010 / 10 / 8$ morning & about 21.1 trillion & about 5.1 trillion & cabinet final decision \\
\hline
\end{tabular}


Notes 1) The narrative announcement on October 22, 2008 referred to a 2 trillion tax cut rather than to a 2 trillion cash handout.

2) The narrative amount in December 2008 includes the amount that was announced in October 2008.

3) National government expenditure in December 2009 includes only central government expenditure.

4) LDP = Liberal Democratic Party, DPJ = Democratic Party of Japan.

Sources: Cabinet Office, Japanese Government, Nikkei Newspaper, Asahi Newspaper, and Yomiuri Newspaper. 
Table 5. Biannual Determinants of Fiscal Expenditure

(1) Dependent variable: total size of package finally decided

\begin{tabular}{|c|c|c|c|c|c|c|}
\hline & \multicolumn{3}{|c|}{ amount with tax cut } & \multicolumn{3}{|c|}{ amount without tax cut } \\
\hline$C$ & $\begin{array}{c}-50.965 \\
(-1.138)\end{array}$ & $\begin{array}{l}3.817 \\
(0.983)\end{array}$ & $\begin{array}{l}-0.170 \\
(-0.053)\end{array}$ & $\begin{array}{l}-52.581 \\
(-1.216)\end{array}$ & $\begin{array}{l}2.986 \\
(0.790)\end{array}$ & $\begin{array}{l}-0.598 \\
(-0.191)\end{array}$ \\
\hline Log(Stock) & $\begin{array}{l}-38.295 \\
(-2.861)^{* *}\end{array}$ & $\begin{array}{l}-22.199 \\
(-2.271)^{* *}\end{array}$ & $\begin{array}{l}-27.584 \\
(-2.891)^{* *}\end{array}$ & $\begin{array}{l}-38.301 \\
(-2.965)^{* *}\end{array}$ & $\begin{array}{l}-22.499 \\
(-2.364)^{* *}\end{array}$ & $\begin{array}{l}-27.340 \\
(-2.961)^{* *}\end{array}$ \\
\hline$\Delta \mathrm{Y}$ & $\begin{array}{l}-106.657 \\
(-3.586)^{* *}\end{array}$ & $\begin{array}{l}-94.210 \\
(-3.489)^{* *}\end{array}$ & $\begin{array}{l}-94.237 \\
(-3.392)^{* *}\end{array}$ & $\begin{array}{l}-103.771 \\
(-3.614)^{* *}\end{array}$ & $\begin{array}{l}-91.036 \\
(-3.463)^{* *}\end{array}$ & $\begin{array}{l}-91.060 \\
(-3.388)^{* *}\end{array}$ \\
\hline$Y$ & $\begin{array}{c}0.511 \\
(1.137)\end{array}$ & & & $\begin{array}{c}0.523 \\
(1.205)\end{array}$ & & \\
\hline DUMMY & & $\begin{array}{l}-7.302 \\
(-1.745)^{*}\end{array}$ & & & $\begin{array}{l}-6.564 \\
(-1.611)\end{array}$ & \\
\hline FALL & $\begin{array}{c}7.301 \\
(1.847)^{*}\end{array}$ & $\begin{array}{c}6.910 \\
(1.787)^{*}\end{array}$ & $\begin{array}{c}7.437 \\
(1.875)^{*}\end{array}$ & $\begin{array}{c}7.352 \\
(1.927)^{*}\end{array}$ & $\begin{array}{c}7.018 \\
(1.864)^{*}\end{array}$ & $\begin{array}{c}7.491 \\
(1.952)^{*}\end{array}$ \\
\hline adj. R- squared & 0.4191 & 0.4466 & 0.4142 & 0.4286 & 0.5048 & 0.4212 \\
\hline \# of obsevations & 39 & 39 & 39 & 39 & 39 & 39 \\
\hline
\end{tabular}

(2) Dependent variable: total size of package initially planned

\begin{tabular}{|l|ccc|ccc|}
\hline & \multicolumn{3}{|c|}{ amount with tax cut } & \multicolumn{3}{c|}{ amount without tax cut } \\
\hline C & -27.5999 & 2.4937 & -0.0718 & -24.7400 & 2.4592 & 0.0376 \\
Log(Stock) & $(-0.991)$ & $(1.041)$ & $(-0.036)$ & $(-0.897)$ & $(1.035)$ & $(0.019)$ \\
& -27.9293 & -18.6593 & -22.1246 & -26.8262 & -18.3305 & -21.6015 \\
$\Delta Y$ & $(-3.357)^{* *}$ & $(-3.095)^{* *}$ & $(-3.746)^{* *}$ & $(-3.256)^{* *}$ & $(-3.065)^{* *}$ & $(-3.702)^{* *}$ \\
& -98.0598 & -91.3113 & -91.3286 & -95.1161 & -89.0412 & -89.0575 \\
Y & $(-5.303)^{* *}$ & $(-5.483)^{* *}$ & $(-5.311)^{* *}$ & $(-5.194)^{* *}$ & $(-5.390)^{* *}$ & $(-5.243)^{* *}$ \\
DUMMY & 0.2768 & & & 0.2491 & & \\
& $(0.991)$ & & & $(0.901)$ & & \\
FALL & & -4.6992 & & & -4.4357 & \\
& & $(-1.821)^{*}$ & & & $(-1.733)^{*}$ & \\
\hline adj. R- squared & 0.601 & 0.7345 & 5.0733 & 4.5250 & 4.2714 & 4.5912 \\
\hline \# of obsevations & 39 & $(1.985)^{*}$ & $(2.066)^{* *}$ & $(1.860)^{*}$ & $(1.805)^{*}$ & $(1.893)^{*}$ \\
\hline
\end{tabular}

Notes 1) The z-statistic is in parentheses, **the $5 \%$ significance level, *the $10 \%$ significance level.

2) $\mathrm{C}=$ constant term, $\log ($ Stock $)=\log$ of lagged stock price divided by its target, $\mathrm{y}=$ lagged output, $\Delta y=$ growth rate of $\mathrm{y}$, Dummy = Koizumi-Abe dummy, FALL = fall season dummy, $\mathrm{G}(-1)=$ total amount in the latest package if fiscal expenditure $>0$, and 0 otherwise. 
Table 6. High-Frequency Determinants of Fiscal Expenditure

(1) Sample Period: 1992 to 2000

\begin{tabular}{|l|cc|cc|}
\hline & \multicolumn{2}{|c|}{ amount with tax cut } & \multicolumn{2}{c|}{ amount without tax cut } \\
\hline C & 5.0880 & 5.3480 & 5.5400 & 5.3030 \\
Log(Stock) & $(3.160)^{* *}$ & $(3.754)^{* *}$ & $(3.246)^{* *}$ & $(3.568)^{* *}$ \\
& -12.2691 & -12.0586 & -5.5646 & -5.7090 \\
Good News & $(-3.231)^{* *}$ & $(-3.267)^{* *}$ & $(-1.541)$ & $(-1.624)$ \\
& 0.3769 & & -0.2931 & \\
Bad News & $(0.370)$ & & $(-0.300)$ & \\
& 1.6900 & 1.4890 & 2.0841 & 2.2378 \\
FALL & $(1.648)$ & $(1.741)^{*}$ & $(2.124)^{* *}$ & $(2.723)^{* *}$ \\
& -3.4578 & -3.5070 & -3.4713 & -3.4317 \\
INITIAL & $(-4.002)^{* *}$ & $(-4.177)^{* *}$ & $(-4.160)^{* *}$ & $(-4.240)^{* *}$ \\
& -5.3561 & -5.3568 & -4.2021 & -4.2098 \\
G(- 1) & $(-5.092)^{* *}$ & $(-5.180)^{* *}$ & $(-3.971)^{* *}$ & $(-4.051)^{* *}$ \\
& 0.5878 & 0.5919 & 0.5264 & 0.5265 \\
\hline adj. R- squared & $(5.704)^{* *}$ & $(5.876)^{* *}$ & $(3.966)^{* *}$ & $(4.037)^{* *}$ \\
\hline \# of obsevations & 0.6950 & 0.7051 & 0.5480 & 0.5639 \\
\hline
\end{tabular}

(2) Sample Period: From 2008 and 2010

\begin{tabular}{|c|c|c|c|c|}
\hline & amount v & th tax cut & amount wi & out tax cut \\
\hline C & 3.7640 & 3.5143 & 5.2648 & 4.5646 \\
\hline & (1.333) & (1.297) & $(2.075)^{*}$ & $(1.771)^{*}$ \\
\hline Log(Stock) & - 13.6134 & - 13.6536 & -11.5873 & - 10.8880 \\
\hline & $(-3.030)^{* *}$ & $(-3.236)^{* *}$ & $(-3.014)^{* *}$ & $(-2.808)^{* *}$ \\
\hline Good News & $\begin{array}{r}-1.0273 \\
(-0.996)\end{array}$ & & $\begin{array}{r}-1.0840 \\
(-1.185)\end{array}$ & \\
\hline Bad News & $\begin{array}{r}-0.6511 \\
(-0.587)\end{array}$ & & $\begin{array}{r}-1.5409 \\
(-1.537)\end{array}$ & \\
\hline FALL & - 6.6797 & - 6.7911 & - 7.1794 & -6.8259 \\
\hline & $(-4.425)^{* *}$ & $(-5.146)^{* *}$ & $(-5.467)^{* *}$ & $(-5.649)^{* *}$ \\
\hline INITIAL & - 1.8856 & -2.1748 & -2.3305 & -2.9422 \\
\hline & $(-1.648)$ & $(-2.115)^{*}$ & $(-2.319)^{* *}$ & $(-3.040)^{* *}$ \\
\hline$G(-1)$ & $\begin{array}{l}0.1817 \\
(1.193)\end{array}$ & $\begin{array}{l}0.1762 \\
(1.351)\end{array}$ & $\begin{array}{l}0.1676 \\
(1.303)\end{array}$ & $\begin{array}{l}0.2166 \\
(1.895)^{*}\end{array}$ \\
\hline$\Delta \mathrm{EX}$ & - 1.1676 & - 1.2292 & - 1.3565 & -1.3439 \\
\hline & $(-2.742)^{* *}$ & $(-3.093)^{* *}$ & $(-3.502)^{* *}$ & $(-3.548)^{* *}$ \\
\hline adj. R- squared & 0.8349 & 0.8438 & 0.8659 & 0.8560 \\
\hline \# of obsevations & 22 & 22 & 22 & 22 \\
\hline
\end{tabular}

Notes 1) The t-statistic is in parentheses, ** the 5\% significance level, *the10\% significance level.

2) $\mathrm{C}=$ constant term, $\log ($ Stock $)=\log$ of lagged stock price divided by its target, FALL $=$ fall season dummy, Good News = good news dummy, Bad News = bad news dummy, 
INITIAL =initial dummy for each fiscal package, $\Delta \mathrm{EX}=$ change of daily exchange rate, $\mathrm{G}(-1)=$ total amount in the latest package if fiscal expenditure $>0$, and 0 otherwise. 
Table 7. Effects of Fiscal Announcements on Stock Prices

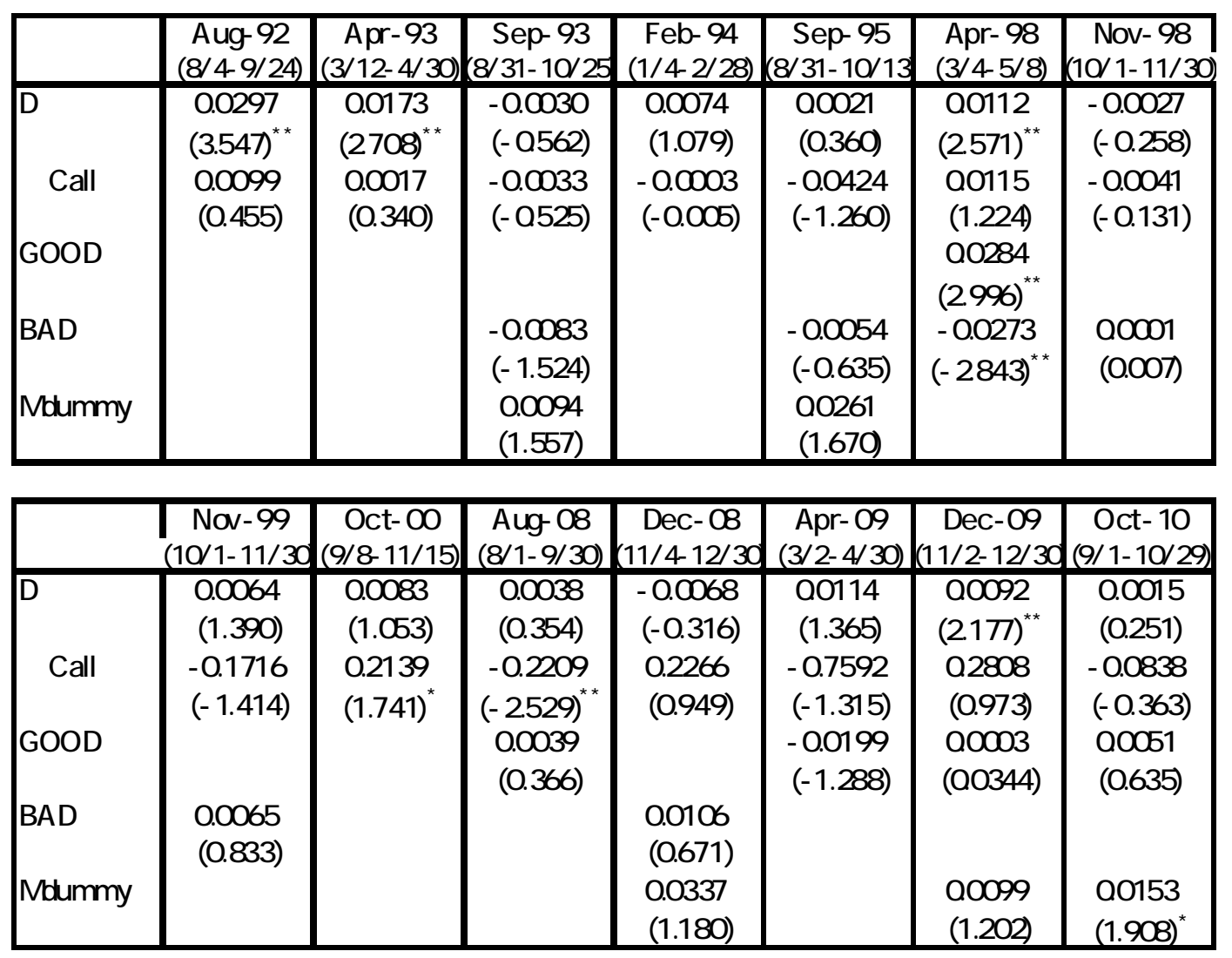

Notes 1 ) The t-value is in parentheses, **the 5\% significance level, *the $10 \%$ significance level.

2) The constant term was included in the regressions but was not shown in the table.

3) GOOD denotes a good news dummy, and BAD denotes a bad news dummy.

4) Mdummy takes one when BOJ cut its policy rate or announced a new easing policy, and zero otherwise.

5) The dates the fiscal policy dummy takes one are as follows.

August-92: Aug. 24 AM, Aug. 25 AM, Aug. 27 AM, Aug. 28 AM. April-93: Apr. 2 AM, Apr. 7

AM, Apr. 12 PM. Sepember-93: Sep. 17 AM. Feb-94: Jan. 26 AM, Jan. 31 AM, Feb. 3 PM, Feb.

9 AM. Sepember-95: Sep. 19 AM, Sep. 20 AM. April-98: Mar. 26 AM, Mar. 30 AM, Apr. 6

AM, Apr. 10 AM, Apr. 24 AM. November-98: Nov. 13 AM, Nov. 16 AM. November-99: Oct.

25 AM, Nov. 4 AM, Nov. 11 AM. October-00: Oct. 16 AM, Oct. 17 AM. August-08: Aug. 29

AM, Sep. 1 AM. December-08: Dec. 19 AM. April-09: Apr. 1 AM, Apr. 7 AM, Apr. 9 AM, Apr.

10 AM. December-09: Dec. 1 AM, Dec. 3 AM, Dec. 4 AM, Dec. 8 AM. October-10: Oct. 4 AM,

Oct. 8 AM. 
Figure 1. General Government Financial Liabilities in Selected OECD Countries

(1) Gross Financial Liabilities

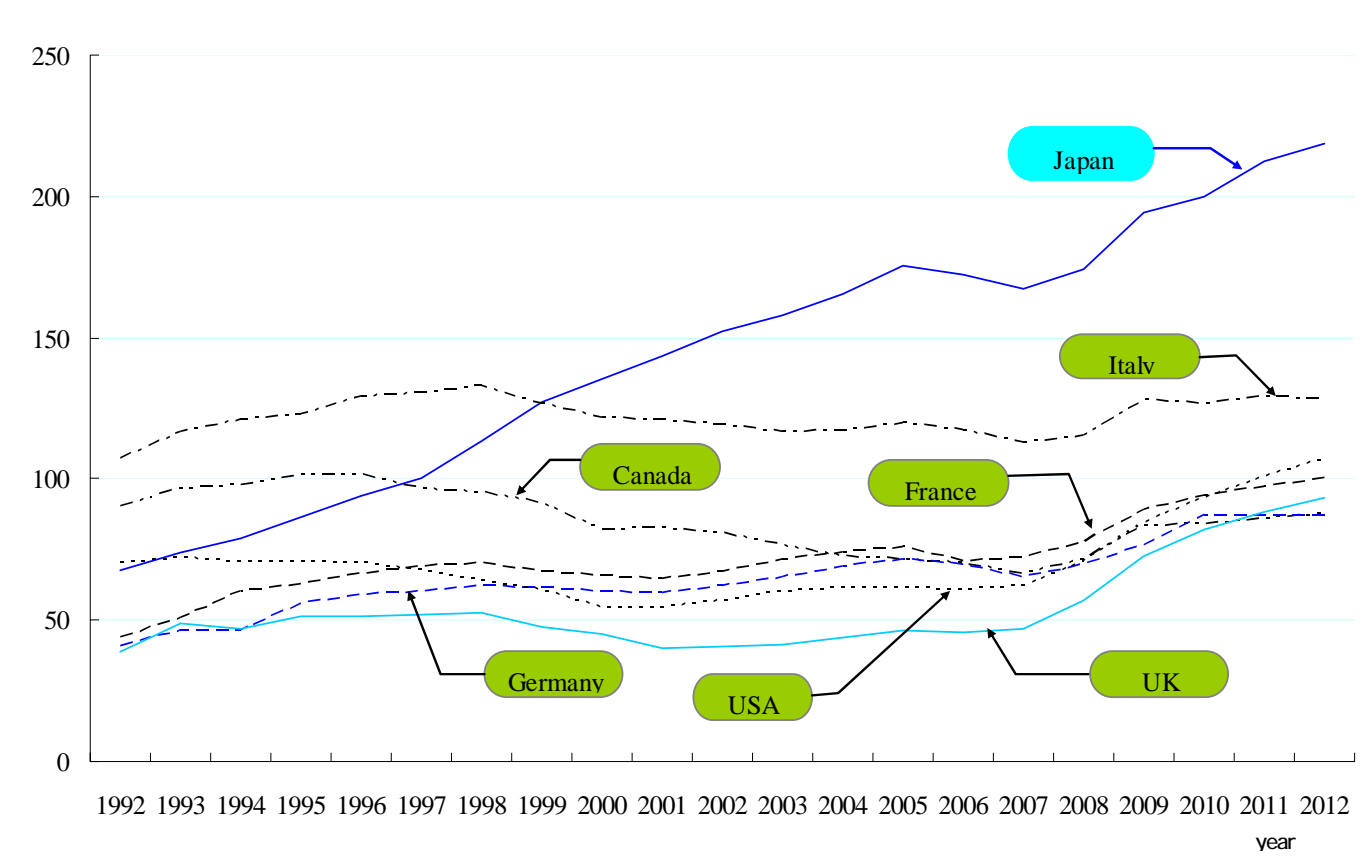

(2) Net Financial Liabilities

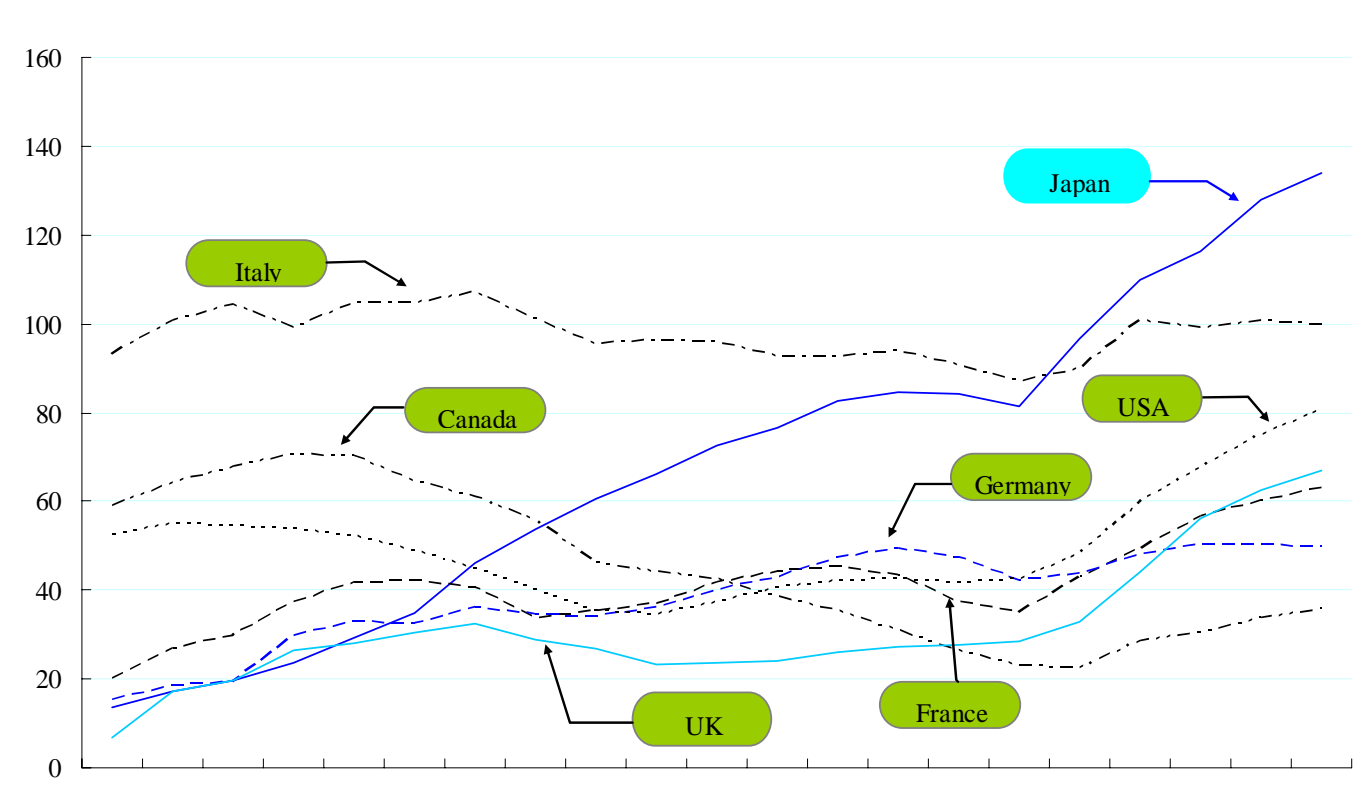

199219931994199519961997199819992000200120022003200420052006200720082009201020112012

Source: OECD Economic Outlook No. 89. 
Figure 2. Actual and Predicted Fiscal Expenditure in Each Stimulus Package

(1) The Period from fall 1992 to fall 2000

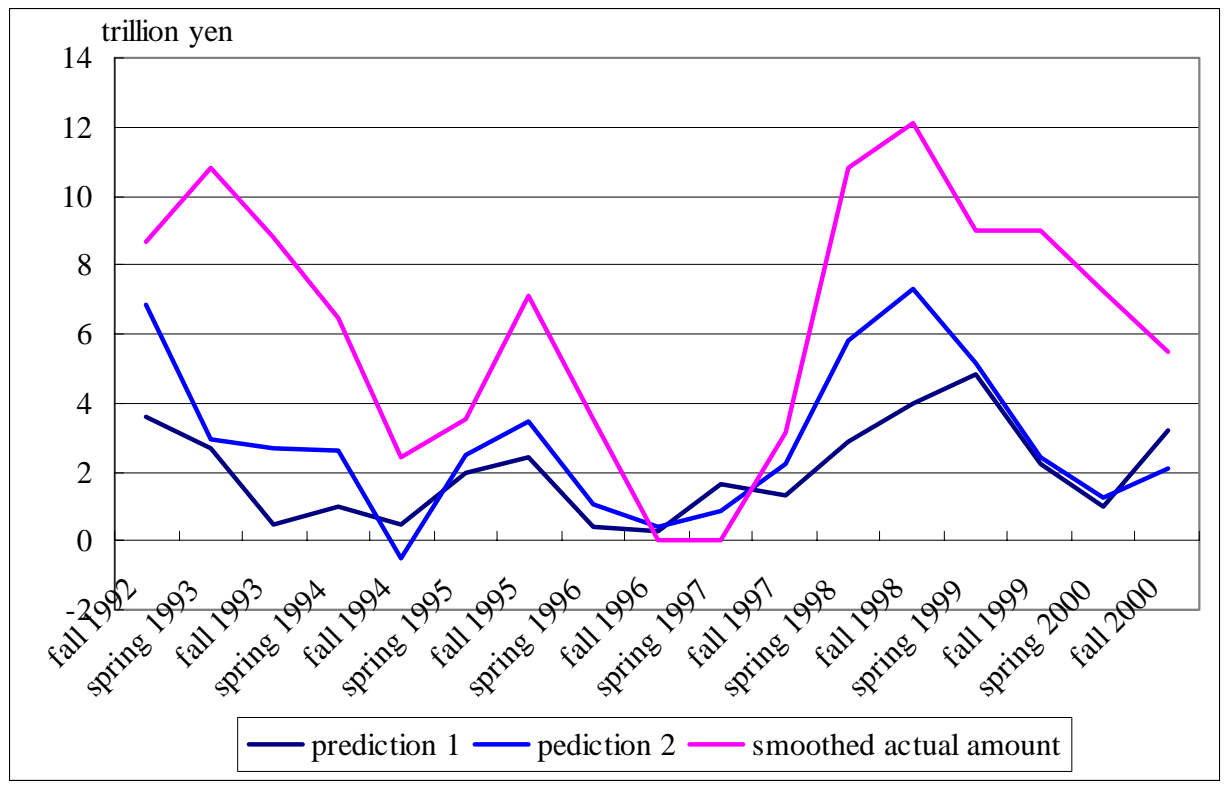

(2) The Period from spring 2001 to fall 2010

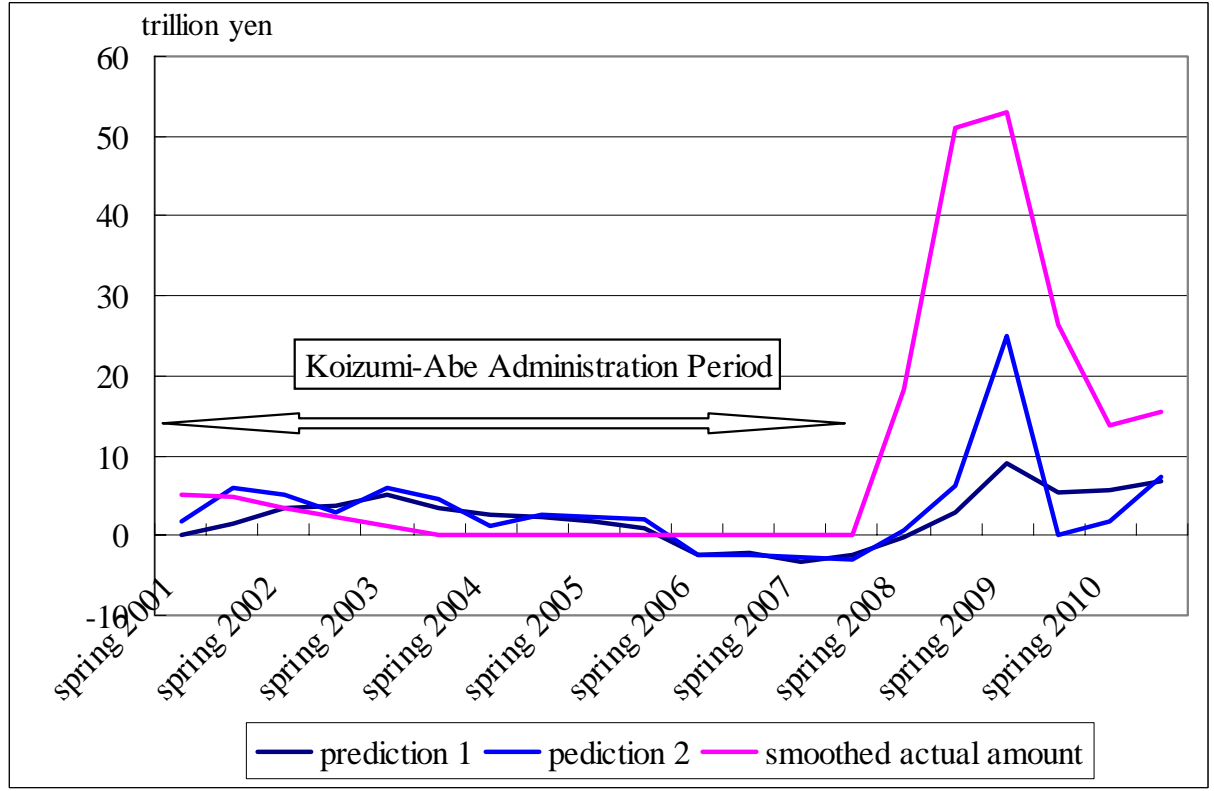

Notes 1) The actual amount was smoothed by taking three-period moving average.

2) Prediction 1 is the predicted amount by the stock price targeting. Prediction 2 is the predicted amount by both the stock price targeting and the output growth targeting. 